\title{
Öğretimde Tasarım Odaklı Düşünme Ölçeğinin Geliştirilmesi ${ }^{1}$
}

\author{
DOI: 10.26466/opus.833362
}

\author{
$\underline{\text { Yeșim Sürmelioğlu }}^{*}$ - Mukaddes Erdem** \\ * Öğr. Gör., Sinop Üniversitesi, Ayancık Meslek Yüksekokulu, Sinop/Türkiye \\ E-Posta: yesimsurmelioglu@gmail.com \\ ORCID: 0000-0003-3073-899X \\ ** Prof. Dr., Hacetepe Üniversitesi, Eğitim Fakültesi, Ankara/Türkiye \\ E-Posta: erdemm@hacettepe.edu.tr \\ ORCID: $\quad \underline{0000-0002-8724-3923}$
}

\section{Öz}

Bu çalışmanın amacı öğretmenlerin, teknoloji tabanlı öğretim tasarımı sürecinde tasarım odakl düşünme yapılarının belirlenmesine ilişkin, geçerli ve güvenilir bir ölçek geliştirmektir. Süreçte öncelikle, alanyazın incelemelerinden hareketle tasarım düşünürünün özelliklerini temsil eden, 62 maddelik bir madde havuzu oluşturulmuştur. Taslak maddeler farklı branştaki 5 öğretmenin ön görüşüne sunulmuştur. Alınan önerilerle gerekli düzenlemeler yapılarak form 8 uzman görüşüne başvurulmuştur. Araştırmanin katılımcıları farklı branş ve kademelerden 630 öğretmenden oluşmuştur. Açımlayıcı faktör analizi sonucunda toplam varyansın \%50.20'sini açıklayan, 25 madde ile 4 faktörden oluşan bir yapı elde edilmiştir. Ölçekte yer alan boyutlar ilişki, süreç, etik ve birey algılarım kapsamaktadır. Doğrulayıcı faktör analizi sonucuna göre, önerilen modele ilişkin uyum indekslerinden RMSEA (.045), SRMR (.043), IFI (.96), GFI (.90), NFI (.90), NNFI (.95), CFI (.96) hesaplanmıştır ve elde edilen değerler iyi uyum gösterdiğinden modelin gözlenen yapıya uygun olduğu ve model olarak doğrulandığı tespit edilmiştir. Ölçeğin iç tutarlılık güvenirliği için Cronbach Alfa katsayısı .93 olarak hesaplanmıştır. Sonuç olarak geliştirilen ölçeğin, öğretmenlerin, teknoloji tabanlı öğretim tasarım sürecinde tasarım odaklı düşünmelerini değerlendirmeye yönelik 25 maddeli ve 4 boyutlu geçerli ve güvenilir bir veri toplama aracı olduğu söylenebilir. Ölçek, yapısı ve genel çerçevesi dâhilinde tasarım odaklı düşünme süreçlerinde tüm öğretmenlere uygulanabilir niteliktedir.

Anahtar Kelimeler: $\quad$ Tasarım Odaklı Düşünme, Tasarım Odaklı Düşünme Ölçeği, Tasarım Düşünürü, Öğretim Tasarımı, Ölçek Geliştirme

\footnotetext{
${ }^{1}$ Bu çalışma, Prof. Dr. Mukaddes Erdem danışmanlığında devam etmekte olan Tasarım Odaklı Düşünmenin Etkili ve Sürdürülebilir Öğretim Teknolojisi Oluşturmaya Katkısı başlıklı doktora tezinden üretilmiştir.
} 
ISSN:2528-9527

E-ISSN: 2528-9535

YIl Year. 11

Cilt Volume: 18

Sayı Issue:39

\title{
Development of Design Thinking Scale in Teaching
}

*

\begin{abstract}
The purpose of this study is to develop a valid and reliable scale to determine the design thinking structure of teachers in the technology-based teaching process. In the process, we primarily, an item pool of 62 items, representing the characteristics of the design thinker, was created based on the literature review. Draft items were presented to the preliminary opinion of 5 teachers from different branches. Necessary arrangements were made with the recommendations received, and 8 expert opinions were consulted on the form. The participants of the research comprised 630 teachers from different branches. As a result of the exploratory factor analysis we obtained a structure explaining $50.20 \%$ of the total variance and comprising 25 items and four factors. The dimensions in the scale include relation, process, ethics and individual perceptions. According to the results of the confirmatory factor analysis we calculated RMSEA (.045), SRMR (.043), IFI (.96), GFI (.90), NFI (.90), NNFI (.95) and CFI (.96), which were among the fit indices regarding the model proposed. Cronbach's alpha internal consistency coefficient for the scale was found to be .93. As the values acquired demonstrated a good fit, the model was appropriate for the structure observed and it was approved as a model. As a consequence we created a four-dimensional valid and reliable data collection tool of 25 items for the scale developed, in order to evaluate the design thinking of teachers in the technology-based teaching design process. The scale can be applied to all teachers in design thinking processes within its structure and general framework.
\end{abstract}

Keywords: Design Thinking, Design Thinking Scale, Design Thinker, Instructional Design, Scale Development 


\section{Giriş}

Bugün eğitim dünyası cevapları kolay bulunamayan birçok karmaşık zorlukla yüz yüze iken tasarım odaklı düşünme (TOD) kavramı, bu zorlukların çözümüne dair nispeten daha yeni bir çalışma ve olanak alanı olarak karşımıza çıkmaktadır. İnsanların daha iyi öğrenip gelişebilmelerine yardım etmek için açık rehberlik sunan öğretim tasarımı (Reigeluth, 1999) alanı ise bu belirsizliğin hem yoğun hem de kritik olduğu alanlardan biridir. Öğretim tasarımı, bireyin belli bir yönde değişimini sağlamak üzere; etkili olacağı düşünülen bileşenleri, bileşenlerin birbiriyle kuracakları ilişkileri, bileşenlerin birbirine göre almaları gereken pozisyonları, bireylerin bunlarla kuracakları etkileşimin biçim, yoğunluk ve süresini, kurulan etkileşimin ortaya çıkarması muhtemel ya da ön görülemeyen sonuçlarının nasıl belirleneceğini ve benzeri birçok şeyi kapsayan bir etkileşim tasarımıdır (Erdem, 2020). Dijital teknolojinin yaşamı dönüştüren etkileriyle büsbütün karmaşıklaşan bu alanda etkililik ise TOD'u zorunlu kılar görünmektedir. Zira, sürecin baş aktörlerinden biri olan öğretmenlerin, bu önemli işlevi yerine getirebilmesi için TOD becerisine sahip olması beklenir. Teknolojiyi öğretim süreçleriyle öğretim tasarımı ilkeleri temelinde buluşturarak etkili öğretim teknolojisi üretmek için; yaratıcı, yenilikçi yani farklı düşünme ve eylemde düşünme becerisine sahip olmak gerekmektedir. Öğretim teknolojisi, öğrenme ve öğretme süreçleri ve kaynaklarının stratejik tasarımı, yönetimi ve uygulanması aracılığıyla, bilgiyi ilerletmenin yanı sıra öğrenmeyi ve performansı iyileştirmek için kuram, araştırma ve iyi uygulamalar çalışması ve etik uygulamasıdır (Association for Educational Communications and Technology [AECT], 2018). Tanım öğretim tasarımı ve teknolojisinin; bireysel, ilişkisel ve etik bir süreç olduğuna işaret etmektedir. $O$ halde, tasarım düşünürü bir öğretmenin bu boyutların tümünde temsil edilebilir bazı özellikler taşımasının beklenebileceği söylenebilir.

Ayrıca dünyada yaşanan pandemi hayatın her alanını etkilemesiyle birlikte özellikle eğitime yönelik bakış açılarını yeniden değerlendirmeyi gerektiren sonuçlar doğurmuştur (Bozkurt, 2020; Bozkurt ve Sharma, 2020). Pandemi ile birlikte çevrimiçi dersler, uzaktan öğretim tasarımları öne çıkmıştır. Çevrimiçi uzaktan öğretim süreçlerinde öğretmenin 
şemasında yer alan bilgileri aktarması yetmemekle birlikte iş birlikli yeni iletişim kanallarının oluşturulması gerekmektedir. Yanı sıra görsel materyal tasarımı, farklı kanallarla bütünsel içerik sunumu, teknoloji tasarımı müdahaleleri kaçınılmaz bir duruma gelmiştir. Bu durumda tasarım odaklı düşünmeye ihtiyaç artmaktadır.

\section{Tasarım Odaklı Düşünme}

Tasarım veya tasarım odaklı düşünme çok farklı disiplinler tarafından ele alınmış ve yorumlanmıştır. Friedman'a (2003) göre tasarım; problem çözme, ihtiyaçları karşılama, koşulları iyileştirme veya yeni ve yararlı şeyler üretme için gerçekleştirilen amaç yönelimli bir süreçtir. Öte yandan bütünleştirici bir disiplin olan tasarımın doğası Friedman (2003) tarafından, doğa bilimleri, beşeri bilimler, sosyal bilimler, hizmetler, sanat, teknoloji ve mühendislik bilimleri olmak üzere altı ortak alanın kesişimine yerleştirilmektedir. Tasarım, bu alanların herhangi birini veya tümünü farklı yönlerde ve oranlarda içerebilir.

Üretken mesleklerde başkaları için değerli yeni şeyler yaratmak istendiğinde temel akıl yürütme biçimi, açılımsal akıl yürütme (abductive) formuna dönüşmektedir. Pek çok araştırmacı (Cross, 1982; Dorst, 2010; Liedtka, 2015; Martin ve Martin, 2009; Owen, 2007) tasarım odaklı düşünmenin karakteristik özelliğinin yapıcı düşünme olduğunu vurgularken tümevarımsal ve tümdengelimsel akıl yürütme türlerinden farklı olarak, açılımsal düşünce olduğunu vurgulamıştır. Bir şeyin (nesnenin, hizmetin, sistemin) yaratılmasının ve paralel olarak çalışma biçiminin belirlenmesi, bu karmaşık başarının gerçekleşmesi, tasarım odaklı düşünmenin çekirdeği olan açılımsal düşünceyi (Dorst, 2010) ifade etmektedir. Brenner, Uebernickel ve Abrell (2016) TOD'u yakınsak ve rraksak düşünme arasında birden çok kez yineleme süreci olarak görmektedir. Diğer problem çözme süreçlerinden farklı olarak TOD, bir sorundan etkilenenlerle işbirliğine ve sorundan etkilenenler için empati geliştirmeyi, sorunun gerçekten onları nasıl etkilediğini anlamaya vurgulamaktadır (Chesson, 2017). Doğası gereği işbirlikli ve katılımcı olan TOD insan merkezli bir yaklaşımdır.

TOD'un farklı alanlarda birçok problemin çözümünde yararlı olduğu düşünülen bir paradigma olma yönünde ilerlediği söylenebilir (Dorst 
2010; Liedtka, 2018; Owen, 2007). TOD, kötü, karmaşık ve kaotik problemlerin çözümü için oldukça etkili bir güce sahiptir (Buchanan, 1992; Rittel ve Weber 1973). Ayrıca TOD insan odaklı tasarımı merkezine alan tüm yenilik etkinliklerini içeren bir yöntemdir (Brown, 2008). TOD, tasarım süreçlerinde yaratıcılığı destekleyen, yaratıcı güven ve yetkinliği vurgulayan, öğretim süreçleri dâhil tüm süreç tasarımlarında geçerli ve kritik olan bir düşünme biçimidir (Rauth, Köppen, Jobst ve Meinel, 2010). TOD, problem algısı ve çeşitli çözüm yollarında derinlemesine öğrenme süreçlerini sürdürerek karmaşık sorunların üstesinden gelmeye yardımcı olur (Kröper, Fay, Lindberg ve Meinel, 2010). TOD, Problem çözmede, çözüme dayalı, insan merkezli, ilişki odaklı bir yaklaşım sunan bir tasarım yöntemidir. Doppelt (2009) tasarım sürecini; problemi tanımlamak ve ihtiyaçları belirlemek, bilgi toplamak, alternatif çözümler üretmek, en uygun çözümü seçmek, bir prototip tasarlamak/geliştirmek ve değerlendirmek olarak aşamalandırmıştır.

Görüldüğü üzere tasarım süreci bünyesinde faklı etkinlikleri barındırır. $\mathrm{Bu}$ doğrultuda bu etkinliklerin akışını kolaylaştırarak mantıksal bir araştırma sistematiği sağlamak için çeşitli TOD modelleri geliştirilmiştir. Her model pek çok farklı disiplinde kullanılabilmektedir. $\mathrm{Bu}$ modellerden biri Stanford Üniversitesi Hasso-Plattner Tasarım Enstitüsü tarafından geliştirilmiştir (The Interaction Design Foundation [IDF], 2020). Bu modele göre tasarım düşüncesinin beş aşaması bulunmaktadır: empatiyle yaklaşmak, tanımlamak, fikir geliştirmek, prototip oluşturmak ve sinamak (test etmek) (IDF, 2020). Çift Elmas Modeli ise bitişik iki elmas üzerinde dört ana aşama sunar (Design Council, 2019). Bu modele göre bir problemi doğru belirlemek, doğru çözümü belirlemek için aynı derecede önemlidir. Model; keşfet, tanımla, geliştir ve sonuçlandır başlıklı dört aşamadan geçmektedir (Design Council, 2019). TOD modelleri aşamaları lineer değildir, sürekli bir yenileme ve değerlendirme içermektedir.

Öğretim tasarımı sürecinde hangi TOD modeli kullanımı tercih edilirse edilsin önemli olan modelin ilgili aşamasında kullanılması en uygun aracı seçmektir. Süreçte tercih edilen araçlar ve yöntemler düşünme biçimiyle uyumlu olduğunda TOD işlemektedir (Brenner, vd., 2016). TOD sürecinde kullanılan çok sayıda araçlar bulunmaktadır. Bunların bazıları şöyle sıralanabilir; gözlem, empati haritası, yolculuk haritası, zihin 
haritası, bağıntı şeması, çaba etki grafiği, beyin fırtınası, tersine beyin fırtınası, kıyaslama tekniği, fikir yenilik ekseni, önceliklendirme, yaşantı senaryo haritası, 5 neden yöntemi. Rauth vd. (2010) TOD yöntemi sürecini işleten öğretmenler ile birebir görüşmelerde tasarım odaklı düşünmenin özüne ilişkin elde ettiği açılamalarda TOD’u bir araç kutusu olarak tanımlayan öğretmenlere rastlamıştır. TOD modeli ve araçları belirlenirken, araştırmanın hedeflerine, amacına uygun olarak araştırmacı veya tasarımcılar tarafından bağlama en uygun olanın tercih edilmesi önerilir.

\section{Tasarım Odaklı Düşünürün Temel Özellikleri}

TOD süreci işletilirken tercih edilen veya geliştirilen model, seçilen araçlar, sürecin akışı ve verimliliği doğrudan tasarım odaklı düşünürün özellikleriyle ilişkilidir. Alanyazında, tasarım odaklı düşünmenin tam potansiyelini ortaya çıkarmanın tasarım düşünürü olmaya geçilme ile olabileceğini vurgulanmaktadır (Chesson, 2017). Başlangıçta tasarım düşüncesinin odağı, organizasyonların tasarım düşüncesini bir yöntem olarak benimsemelerini sağlamak olmuştur. Ancak günümüzde sadece yöntemi uygulamak yeterli olmamaktadır, TOD yeteneklerine hâkim olunmalidır (Brown, 2008).

Tasarım odaklı düşünür kavramının, TOD pratiği ve yetkinliğinin tasarım bağlamının ötesinde, akademik tasarım altyapısına sahip olmayan insanlar için de kullanıldığı görülmektedir (JohanssonSköldberg, Woodilla ve Çetinkaya, 2013). Brown (2008), tasarım düşüncesine sahip olan insanların mutlaka tasarım eğitimi almak zorunda olmadığını belirterek tasarım düşüncesine sahip bireyleri empati kurabilir, bütünsel düşünebilir, iyimserdir, deneyseldir ve işbirliklidir şeklinde belirtmiştir. TOD çok sayıda alternatif çözüm içeren açılımsal düşünceye ve deneylere dayanırken belirsizliğin yüksek olduğu karar bağlamlarında en uygun olanı tercih edebilen bireylere tasarım düşünürü denir (Liedtka, 2015). Bu doğrultuda tasarım odaklı düşünürler, geleceğe odaklanmış hipotez temelli sonuçlar üreten, radikal yenilik üretme potansiyeline sahip ve düşüncede çevik (Howard ve Davis, 2011; Liedtka, 2015) bireylerdir. 
Chesson (2017) tasarım düşünürünün özelliklerini, dinamik bir zihin, insan merkezli, empatik, görsel, belirsizlikte rahat, prototip oluşturan, yansıtıcı, risk almaya açık, başarısızlığı kucaklayan, işbirlikli, iyimser şeklinde sıralamıştır. Dosi, Rosati ve Vignoli (2018) tasarım odaklı düşünürün özelliklerini, risk ve belirsizliği kucaklayan, insan merkezli, empatik, süreç farkındalığı yüksek, bütüncül bakış açısı, sorun çözme, disiplinler arası işbirliği, çeşitliliğe açı, öğrenme odaklı, eleştirel sorgulama, açlımsal düşünme, öngörebilme ve iyimserlikten oluşan düşünce yapıları olarak sıralamıştır. Tasarım düşünürleri, henüz var olmayan çözümleri düşünebilir ve bu çözümleri fiziksel dünyaya getirmek için eskiz (taslak) ve haritalama gibi teknikleri kullanarak görsel tasarım stili özelliğe sahiptir (Boni, Weingart ve Evenson, 2009; Junginger, 2007; Liedtka, 2018).

Razzouk ve Shute (2012) tasarım uzmanlarının temel özelliklerini çözüm üretmeyi, sentezlemeyi, değerlendirmeyi yapabilenler olarak açıklarken aynı zamanda bu becerilerin performansa dayalı ölçümlerini tasarlayıp geliştirmenin oldukça zor olduğunu belirterek tasarım düşünme becerilerinin performansa dayalı geçerli bir değerlendirme ölçümüne ihtiyaç olduğunu vurgulamıştır. Akademik literatür, tasarım odaklı düşünürünün, düşünce yapısının temel unsurlarının ne olduğu ve ölçümü konusunda uzlaşamamıştır (Dosi vd., 2018; Razzouk ve Shute, 2012). Buna rağmen araştırmaların çoğunda tasarım düşünürünün ortak özelliklerine rastlanılmaktadır.

Alanyazından elde edilen veriler incelendiğinde öğretim tasarımcısı olan öğretmen, olasılıklar ve sinırlılıklar arasında deney yoluyla öğrenmeye dayanan yinelemeli bir süreci her zaman işletir ve bu sürecin TOD ile daha olanaklı hale gelebileceği söylenebilir.

\section{Öğretim Süreçleri Tasarımında Tasarım Odaklı Düşünme}

Brown (2008) tasarım sürecini yaratıcı, insan merkezli bir keşif süreciyle güçlendirilen ve ardından prototip oluşturma, test etme ve iyileştirme işlemlerini tekrar eden yoğun çalışmasının sonucu olduğunu açıklamıştır. Bu açıdan bakıldığında TOD, özellikle eleştirel düşünen öğretmenler için dinamik bir güdüleme desteği ve öğretmenlerin kendilerine güven duymasını sağlayabilir (Scheer, Noweski ve Meinel, 2012). Scheer, Noweski ve Meinel (2012) öğretmen eğitiminde TOD araştırmalarına 
ihtiyaç olduğunu vurgulayarak, pedagoji bilimindeki teorik bulgular ile okullardaki gerçek uygulamayı hayata geçirme arasındaki eksik bağlantıyı TOD ile gideribileceğini vurgulanmıştır. Tsai ve Chai (2012) öğretmenlerin bir ürün geliştirmede önlerindeki engelin tasarım düşüncesi zayıflı̆̆ı olduğunu belirtmiştir. TOD, öğretmenlerin farklı bir şey yapmaya dair farklı seçenekler ortaya koyma ya da yapma becerilerini içeren yaratıcı bir düşünme formuna sahip olma düzeyi ile ilgilidir. Bu doğrultuda teknoloji ve öğretim tasarımında, tasarım düşünürü olan öğretmenin temel özellikleri nasıl olmalıdır sorusuna yanıt aranarak elde edilen yanıtlar değerlendirilerek bir ölçme aracına dönüştürülmeye karar verilmiş ve öğretim tasarımı alanına özgü boyutlar ortaya çıkarılarak TOD becerileri ile ilişkilendirilmiştir. Öğretim tasarımı etkili öğretim ortamları oluşturma, öğrenmeyi belli amaçlarla yönlendirme, ilişkilendirme, denemelik bir öğretimsel süreç tasarımıdır (Erdem, 2020). Öğretim tasarımı ve teknolojisi alanı veya teknoloji tabanlı öğretim tasarımları incelendiğinde süreç gerektiren, bireysel çalışmalarla, etkileşimli ilişkilerin etik olarak sürdürülmesi gerektiği öne çıkmıştır.

Araştırma kapsamında tasarım odaklı düşünürün ve öğretim tasarımcısının temel özellikleri birleştirilerek tasarım odaklı düşünür olan öğretmenin taşıması veya geliştirilmesi gereken 13 özellik belirlenmiştir. Belirlenen özellikler ilişki, süreç, birey ve etik boyutlarında sınıflandırılmıştır. Bu 13 özelliğin ayrı faktörler olarak ortaya çıkmama ihtimaline rağmen birbirleriyle ilişki olabileceği düşünülen özellikler bir boyut altında toplanarak dört faktör yapısının olabileceği planlanmıştır (Tablo 1).

Tablo 1. Tasarım odaklı düşünürün özellikleri

\begin{tabular}{llll}
\hline İlişki & Süreç & Birey & Etik \\
\hline İnsan merkezli & Deneme yönelimi/risk almaya açı & Yenilikçi/belirsizlikte rahat & Etik \\
Empati & Yaratıcı güven & İyimserlik & \\
Yansıtıcı & Bütünsel bakış & Eleştirel sorgulama & \\
İşbirlikli ekip çalışması & Dinamik bir zihin & Tasarım stili & \\
\hline
\end{tabular}

TOD ile öğretimi tasarlayan her öğretmende bulunması beklenen 13 özelliğin birey, ilişki, süreç ve etik boyutları ile teknoloji tabanlı öğretim süreçlerinde $\mathrm{TOD}^{\prime} \mathbf{u}$ temsil ettiğine karar verilmiştir. Her yapının özellikleri literatürden yararlanılarak kısaca açıklanmıştır. 
İnsan (Birey) Merkezli: İnsan merkezli olma, karmaşık ve stratejik sorunları çözmenin bir yolu olan insan davranışlarını, ihtiyaçlarını ve değerlerini anlamaya odaklanmak anlamına gelmektedir (Howard ve Davis, 2011). Doğası gereği işbirlikli ve katılımcı olan TOD literatür odaklı bir yaklaşım değil, insan merkezli bir yaklaşımdır (Howard ve Davis, 2011). İnsan merkezli TOD, beklenmedik içgörüler yakalayacak ve insanların istediklerini, ihtiyaçlarını, tercihlerini daha kesin olarak yansitan yenilikler üretecektir (Brown, 2008).

Empati: Empati, insan merkezli bir öğretim tasarımı sürecinin temelidir. Bir tasarım düşünürü, insanların bir sorundan nasıl etkilendiğini anlamakla ilgilendikleri için insan merkezlidir ve bu insan merkezli yaklaşım tasarım düşünürlerinin insanlara ve karşılaştıkları sorunlara karşı empatik olmalarını sağlar (Brown, 2008; Kimbell, 2011). Empati bir sorunu, problemden etkilenenlerin bakış açısından anlama veya görme yeteneğidir (Brown, 2008; Chesson, 2017; Martin ve Martin, 2009). Empati bir başkasının duygularını, düşüncelerini ve deneyimlerini anlama, farkında olma, duyarlı olma ve dolaylı olarak deneyimleme eylemidir.

Yansıtıcı: Yansıtma, tasarım odaklı düşünürün mevcut sorun hakkında, bilinenlere uygulanabilecek geçmiş deneyimlerden neler bildiklerini anlamak için geriye bakma süreci olarak tanımlanır (Chesson, 2017). Tasarım odaklı düşünme sürecinde içgörünün oluşması da denilebilir (Dosi vd., 2018). Tasarım sürecinin her aşamasında gelen yorumlar ve olası etkiler üzerine düşünmedir.

İşbirlikli Ekip Çalışması: Söz konusu özelliklerin ortaya çıkması için işbirlikli çalışmalar büyük öneme sahiptir. Ürünlerin, hizmetlerin ve deneyimlerin artan karmaşıklığı, tek bir tasarımcının yerini, disiplinlerarası işbirlikli gerçeğiyle değiştirmiştir (Brown, 2008). Tasarım düşünürleri daha iyi iletişim kurmak ve süreci açılığa kavuşturmak için işbirliği yapmalı, bilgilerini görselleştirme araçlarını kullanarak paylaşmalı ve tartışmalıdır (Dosi vd., 2018). Bir öğretmen hiçbir ortamda yalnız değildir ve işbirliği içerisinde yol alması tasarımlarını kolaylaştırmaktadır. 
Deneme Yönelimi/Risk Almaya Açıklık: Öğretimde bir değere ulaşmak için deneme yapmaya ihtiyaç duyulur ve her deneme bir riske açılıktır. Deneme yönelimi, risk almaya açıklık veya riski kucaklamak olarak da ifade edilebilir. Riski kucaklama bağlam ve yeni durumların derinlemesine araştırılmasına olanak tanıyan süreç açısından risk alma eğilimi içerir (Dosi vd., 2018). Tasarım düşünürleri, başarısız denemelerde kendilerine güvenirler ve başarısızlıkları yeni fırsatları keşfetme ve yeni öğrenmelerin başka bir yolu olarak görürler (Dosi vd., 2018).

Yaratıcı Güven: Yaratıcllık, problemlere yeni bir gözle bakabilmenin düşünsel boyuttaki eylemidir ve bu eylem gelişen süreçteki fırsatları fark ederek yeni fikirler ve yaklaşımlar üretmeyi sağlamaktadır (Akdemir, 2017). Tasarım süreçlerinde yaratıcılığı destekleyen, yaratıcı güven ve yetkinliğini vurgulayan, öğretim süreçleri dahil tüm süreç tasarımlarında geçerli ve kritik olan bir düşünme biçimidir (Rauth vd., 2010).

Bütünsel Bakış: Tasarım düşünürünün farklı disiplinlerden, farklı algıları ve bakış açıları olan veya diğer kuruluşlardan insanlarla işbirliği yapması beklenir (Dosi vd., 2018). Bütünsel bakış problemi yaşayanların kendilerini nasıl etkilediğini anlamak, bir sorunun meydana geldiği bağlamda incelemek ve bir problemin insanlar üzerindeki etkisi için empati geliştirerek etkileşimde bulunmaktır (Chesson, 2017). Bütünsel bakış yansıtıcı düşünmeyi, eleştirel sorgulamayı, empatiyi içinde barındırmaktadır.

Dinamik Bir Zihin: TOD, problem çözmeyi yinelemeli bir süreç olarak gören, yaratıcı güven ile fikir üreten, çoklu perspektifleri göz önünde bulunduran, fikirleri değerlendirmek için analitik düşünceye kolayca geçebilen bir düşünce yapısını içerisinde barındıran dinamik bir zihin gerektirir (Brown, 2008; Chesson, 2017; Martin ve Martin, 2009). Kendinden farklı bakış açılarını anlamak, çözüm tasarımında doğrusal bir yoldan çok sarmal bir süreç izleyerek çözüm tasarımına her zaman birden fazla yol bulmaktır.

Yenilikçi/Belirsizlikte Rahat: TOD ile tasarımcının henüz var olmayan çözümler üretmesi ve bilinmeyeni keşfetmesi gerekir (Chesson, 2017). 
Alanyazında yenilikçi ve belirsizlikte rahat özelliklerini farklı olarak ele alan çalışmalara rastlanılmıştır. Ancak bu çalışma kapsamında öğretim tasarımında yeniliğe açı olan bir öğretmen aynı zamanda belirsizlikten de rahatsızlık duymayacak biçiminde yorumlanmaktadır.

Iyimserlik: TOD kapsamında iyimserlik tüm sorunların en az bir potansiyel çözümü olduğu inancı anlamına gelmektedir. Belli bir sorunun kısıtlamalarına en az bir çözümün mevcut alternatiflerden daha iyi olduğu varsayımına dayanır (Brown, 2008). Tasarım düşünürü var olan durumdan daha iyi bir durumun olduğuna inanarak sürece iyimserlikle yaklaşır.

Eleştirel Sorgulama: Eleştirel sorgulama sorular sorma yeteneği veya her şeyi sorgulama alıştırmasıdır (Dosi vd., 2018). Eleştirel sorgulama bilinmeyen, belirsiz bir şeyi merak etme ve farklı durumları mümkün olduğunca çok düşünmeyi gerektirir.

Tasarım Stili: Tasarım düşünürünün fikirlerini, düşüncelerini çözümlerini görselleştirmesi beklenmektedir. Tasarım düşünürü neyin var olabileceğini, olayların nasıl olabileceğini anlamak ve zihininde oluşturulan fikirleri fiziksel dünyaya getirmek için eskiz ve haritalama kullanır (Boni, Weingart ve Evenson 2009; Chesson, 2017; Junginger, 2007). Boni, Weingart ve Evenson (2009) inovasyon sürecindeki bilgiyi görselleştirme becerisini kritik bir yere yerleştirerek soyut düşünceden fikirleri görselleştirmeye ve daha sonra bu görselleştirmeler üzerine yeniden düşünmeye geçilmesini, yenilikçi tasarımın kalbi olarak ifade etmektedir. Eskizin güzel çizimler olması gibi bir kaygı güdülmez amaç görsel anlatımla fikirleri yakalamak ve çözümler keşfetmektir.

Etik: Her bireyin etik olması beklenirken, bir öğretim tasarımcısı olan öğretmenin etik olması çok daha önemlidir. Etik meslek sürecinde tarafların uyması veya kaçınması gereken davranışlar bütünüdür (Türk Dil Kurumu [TDK], 2020). Öğretmenin tasarım odaklı düşünürken ulaşmak istediği değere gideceği yolda ilham aldığı fikirleri, fikirlerin sahiplerini, kaynakları, açık olarak belirtmesi gerekmektedir. Bu bağlamda öğretimi tasarlayan öğretmen yararlandığı kaynakları açıkça 
ifade etmeyi önemsemelidir. Bu davranış göstergesine de etik denilerek öğretmenin etik olması beklenmektedir.

Belirlenen bu özelliklerle teknoloji tabanlı öğretim tasarımında TOD ilişki odaklı, insan merkezli, etik bir süreci temsil etmektedir. Yapılan alanyazın taramasında karşılaşılan araştırmalarda öğretim tasarımı ve teknolojisi alanındaki değerleri kapsamlı bir şekilde bir araya getiren bir ölçeğe rastlanılmamıştır. Bu alanda öğretmenlerin tasarım odaklı düşünmelerini ölçmeye çalışan bir ölçek geliştirme çalışmasına ihtiyaç duyulmaktadır. $\mathrm{Bu}$ nedenle öğretim tasarımı ve teknolojisi alanında öğretmenlere yönelik Tasarım Odaklı Düşünme Ölçeği (TODÖ) geliştirme çalışmasının yapılmasına karar verilmiştir. Bu çalışmanın amacı öğretmenlerin TOD yapılarının belirlenmesine ilişkin, geçerlik ve güvenirlik çalışmaları yapılmış bir ölçme aracı geliştirmektir. Bu aracın hem araştırma hem de uygulama için yararlı olacağı düşünülmektedir.

\section{Yöntem}

$\mathrm{Bu}$ araştırmada amaç, öğretmenlerin, teknoloji tabanlı öğretim tasarımı sürecinde TOD yapılarının belirlenmesine ilişkin geçerli ve güvenilir bir ölçme aracı geliştirmektir. Araştırma kapsamında açımlayıcı ve doğrulayıcı faktör analizi sonuçlarına dayalı olarak öğretmenlerin TOD yapılarını belirleyen bir ölçme aracı geliştirilmiştir.

\section{Katılımcilar}

Çalışmanın katılımcıları farklı branş ve kademedeki öğretmenlerden oluşmuştur. Veriler 2019-2020 öğretim yılı yaz döneminde toplanmıştır. Elektronik form aracilığı ile ölçek öğretmenlere ulaştırılmıştır. 659 öğretmen geri dönüş sağlamıştır. Ancak 29 öğretmenin verisi aşırı uç değerde yer aldığından çıarılarak 630 öğretmen verileri ile işlemler yapılmıştır. Katılımcıların demografik bilgileri aşağıdaki tabloda yer almaktadır. 
Tablo 2. Katılımcıların demografik özellikleri

\begin{tabular}{|c|c|c|c|}
\hline \multirow[t]{16}{*}{ Değişkenler } & & $n$ & $\%$ \\
\hline & Beden Eğitimi Öğretmeni & 6 & 1.0 \\
\hline & Bilişim Teknolojileri Öğretmeni & 38 & 6.0 \\
\hline & Biyoloji Öğretmeni & 32 & 5.1 \\
\hline & Coğrafya Öğretmeni & 57 & 9.0 \\
\hline & Din Kültürü ve Ahlak Bilgisi Öğretmeni & 9 & 1.4 \\
\hline & Felsefe Öğretmeni & 13 & 2.1 \\
\hline & Fen Bilgisi Öğretmeni & 52 & 8.3 \\
\hline & Fizik Öğretmeni & 10 & 1.6 \\
\hline & İlköğretim Matematik Öğretmeni & 21 & 3.3 \\
\hline & İngilizce Öğretmeni & 31 & 4.9 \\
\hline & Kimya Öğretmeni & 8 & 1.3 \\
\hline & Matematik Öğretmeni & 23 & 3.7 \\
\hline & Okul Öncesi Öğretmeni & 20 & 3.2 \\
\hline & Sınıf Öğretmeni & 35 & 5.6 \\
\hline & Sosyal Bilgiler Öğretmeni & 72 & 11.4 \\
\hline \multirow[t]{9}{*}{ Branş } & Tarih Öğretmeni & 22 & 3.5 \\
\hline & Türk Dili ve Edebiyatı Öğretmeni & 30 & 4.8 \\
\hline & Türkçe Öğretmeni & 22 & 3.5 \\
\hline & Resim Öğretmeni & 24 & 3.8 \\
\hline & Müzik Öğretmeni & 4 & 0.6 \\
\hline & Rehber Öğretmeni & 12 & 1.9 \\
\hline & Teknoloji ve Tasarım Öğretmeni & 38 & 6.0 \\
\hline & $\begin{array}{l}\text { Meslek Öğretmenleri (grafik ve fotoğraf, sağlık hizmetleri, aile ve } \\
\text { tüketici hizmetleri, güzellik ve saç bakım hizmetler, büro yönetimi, } \\
\text { muhasebe ve finansman, elektrik-elektronik, program geliştirme, tekstil, } \\
\text { pazarlama, yiyecek içecek hizmetleri, çocuk gelişimi ve eğitimi, adalet, } \\
\text { makine bölümü, tesisat teknolojisi ve iklimlendirme, drama eğitmeni, } \\
\text { yaratıcı okuma, sanat tarihi, seramik, metal teknolojisi, kuyumculuk } \\
\text { teknolojisi, moda tasarım, endüstriyel otomasyon teknolojileri, el } \\
\text { sanatları/nakış teknolojisi) }\end{array}$ & 51 & 8.1 \\
\hline & Toplam & 630 & 100 \\
\hline \multirow{4}{*}{$\begin{array}{l}\text { Öğretim } \\
\text { kademesi }\end{array}$} & İlkokul & 64 & 10.2 \\
\hline & Ortaokul & 247 & 39.2 \\
\hline & Lise & 319 & 50.6 \\
\hline & Toplam & 630 & 100 \\
\hline \multirow{4}{*}{$\begin{array}{l}\text { Çalıştığ } 1 \\
\text { kurum türüu }\end{array}$} & Kamu & 467 & 74.1 \\
\hline & Özel & 157 & 24.9 \\
\hline & Diğer (Bağımsız, halk eğitim) & 6 & 1.0 \\
\hline & Toplam & 630 & 100 \\
\hline \multirow{3}{*}{ Cinsiyet } & Kadın & 431 & 68.4 \\
\hline & Erkek & 199 & 31.6 \\
\hline & Toplam & 630 & 100 \\
\hline \multirow{8}{*}{ Yaş aralığı } & $20-25$ & 16 & 2.5 \\
\hline & $26-30$ & 144 & 22.9 \\
\hline & $31-35$ & 116 & 18.4 \\
\hline & $36-40$ & 127 & 20.2 \\
\hline & $41-45$ & 80 & 12.7 \\
\hline & $46-50$ & 81 & 12.9 \\
\hline & 51 ve üstü & 66 & 10.5 \\
\hline & Toplam & 630 & 100 \\
\hline
\end{tabular}




\begin{tabular}{|c|c|c|c|}
\hline \multirow{7}{*}{$\begin{array}{l}\text { Hizmet } \\
\text { süresi aralığı }\end{array}$} & $1-5$ & 154 & 24.4 \\
\hline & $6-10$ & 127 & 20.2 \\
\hline & $11-15$ & 88 & 14.0 \\
\hline & $16-20$ & 85 & 13.5 \\
\hline & $21-25$ & 96 & 15.2 \\
\hline & 26 ve üstü & 80 & 12.7 \\
\hline & Toplam & 630 & 100 \\
\hline \multirow{5}{*}{$\begin{array}{l}\text { En son } \\
\text { mezun } \\
\text { olunan } \\
\text { program }\end{array}$} & Ön lisans & 1 & 0.2 \\
\hline & Lisans & 490 & 77.8 \\
\hline & Yüksek lisans & 130 & 20.6 \\
\hline & Doktora & 9 & 1.4 \\
\hline & Toplam & 630 & 100 \\
\hline \multirow{3}{*}{$\begin{array}{l}\text { Tercih ettiği } \\
\text { öğretim türü }\end{array}$} & Yüz yüze öğretim & 594 & 94.3 \\
\hline & Uzaktan çevrimiçi öğretim & 36 & 5.7 \\
\hline & Toplam & 630 & 100 \\
\hline
\end{tabular}

\section{Ölçek Geliştirme Süreci}

TODÖ geliştirme sürecinde; literatür taraması, madde havuzu oluşturma, uzman görüşlerinin alınması, maddelerin düzenlenmesi, uygulama, istatistiksel analizler, en son testin oluşturulması, geçerlik, güvenirlik, faktör analizi, standardizasyon çalışması sıralamasıyla (Şeker ve Gençdoğan, 2014) yürütülmüştür. Süreç aşağıda detaylı olarak açıklanmıştır.

TOD öçeği geliştirmek amacıyla öncelikle TOD ile ilgili alanyazın taraması yapılmıştır. Ülkemizde ve yurt dışında yapılmış olan çalışmalar incelenmiş yurt dışında yapılan çalışmalarda TOD konulu anket ve ölçek çalışmalarına rastlanılmış ve maddeler kontrol edilmiştir. Özellikle genel hedef kitleye hitap eden Dosi vd. (2018) ve Chesson (2017) çalışmalarındaki maddeler öğretim tasarımı ve teknolojisi alanına uyarlanarak madde havuzuna alınmıştır. Farklı alanlara ve yaş seviyelerine göre tasarım düşüncesine yönelik ölçme araçları geliştiren çalışmalara rastlanılmış, ancak öğretim tasarımı ve teknolojisi alanında kullanılmasının olanaklı olmadığına karar verilmiştir. Bunların bazıları, mühendislik öğrencilerinin TOD becerilerini belirlemeye yönelik geliştirilen ölçme aracı (Blizzard, Klotz, Potvin, Hazari, Cribbs ve Godwin, 2015), sistem mühendislerine yönelik TOD tutum ölçeği (Greene, Gonzalez ve Papalambros, 2019), ilkokul ve orta öğretim öğrencilerine yönelik TOD testi (Rusmann ve Bundsgaard, 2019). 
Ölçek geliştirme çalışmalarında başlangıçta madde havuzuna dahil edilmesi gereken madde sayısını belirlemek imkansız olmasına rağmen madde havuzu ne kadar büyük olursa o kadar iyi olarak kabul edilmektedir (Büyüköztürk, 2002; DeVellis, 2016). Çalışmada ölçülmesi hedeflenen özelliğin kuramsal yapısının belirlenmesi için TOD temelinde geliştirilen ölçeklerden ve kavramsal çalışmalardan faydalanılarak 62 maddelik bir madde havuzu oluşturulmuştur. İlk taslak maddeler farklı branştaki 5 öğretmenin ön görüşüne sunulmuştur. Buradaki amaç araştırmanın hedef kitlesi olan öğretmenlerin maddeleri yantlarken nelere dikkat ettiğini tespit ederek incelemeler yapmaktır. Alınan görüşler, araştırmacılar tarafından değerlendirilerek madde sayısı 59'a düşürülmüştür. Ardından ölçeğin görünüşü ve kapsamı açısından uzman görüşüne başvurulmuştur. TOD disiplinler arası bir süreci temsil ettiğinden ve öğretim tasarımı ve teknolojisi alanı da bütün pedagojide kullanıldığından maddelere ilişkin uzman görüşü eğitim bilimlerinde farklı disipline mensup uzmanlardan alınmıştır. Ölçeğin sunulduğu uzmanlardan ikisi TOD ile ilgili çalışmaları bulunun Türkçe ve Sosyal Bilimler Eğitimi ve Özel Eğitim Bölümü, diğer beş uzmanın bölümü; Eğitim Bilimleri, Temel Eğitim, Matematik ve Fen Bilimleri Eğitimi, Bilgisayar ve Öğretim Teknolojileri Eğitimi. Uzmanların ölçek maddelerine ve ilgili boyuta ilişkin maddelerin temsil edicilik derecesi (13), anlaş1lırlık derecesi (1-3) ve varsa önerilerini yazabilecekleri bir form eposta aracilığıyla gönderilmiş ve alınmıştır.

Uzman görüşleri alındıktan sonra her bir madde için uzmanların görüşleri tek tek incelenmiş ve maddelere yönelik gelen önerilerle maddeler yeniden düzenlenmiştir. Düzeltmelerle 59 maddelik taslak ölçek formu oluşturulmuş ve uygulamaya hazır hale getirilmiştir. Alanyazın ile belirlenen özelliklere yönelik maddelerin dağılımının uyumlu olmasına dikkat edilmiştir. Maddelerin ölçtüğü özelliğe ilişkin dağılım Tablo 3'de verilmiştir.

Ölçek, $6^{\prime}$ lı likert türü dereceleme (0 ilgili maddede belirtilen durumun hiç uymadığı, 5 ise tam olarak uyduğu) maddelerinden oluşmaktadır. Bilindiği gibi likert tipi ölçekler bireyin kendisi hakkında bilgi vermesi (self report) esasına dayanmaktadır (Tezbaşaran, 1997). Maddelerin yerleşimi karıştırılarak elektronik form aracılığı ile öğretmenlere ulaştırılmıştır. Form yaklaşık iki ay veri toplamaya açık kalmıştır. Ayrıca 
form üzerinde katılımcının ölçeği gönüllü olarak cevapladığına dair bir kontrol sorusu da yerleştirilmiştir.

Tablo 3. Madde özellikleri dă̆ılımı

\begin{tabular}{|c|c|c|c|c|c|c|c|}
\hline İlişki & $\begin{array}{l}\text { Madde } \\
\text { Sayısı }\end{array}$ & Süreç & $\begin{array}{l}\text { Madde } \\
\text { Sayısı }\end{array}$ & Birey & $\begin{array}{l}\text { Madde } \\
\text { Sayısı }\end{array}$ & Etik & $\begin{array}{l}\text { Madde } \\
\text { Sayısı }\end{array}$ \\
\hline $\begin{array}{l}\text { İnsan } \\
\text { merkezli }\end{array}$ & 6 & $\begin{array}{l}\text { Deneme } \\
\text { yönelimi/risk } \\
\text { almaya açık }\end{array}$ & 6 & $\begin{array}{l}\text { Yenilikçi / } \\
\text { belirsizlikte } \\
\text { rahat }\end{array}$ & 6 & Etik & 6 \\
\hline Empati & 4 & $\begin{array}{l}\text { Yaratıcı } \\
\text { güven }\end{array}$ & 3 & İyimserlik & 4 & & \\
\hline Yansiticl & 3 & $\begin{array}{l}\text { Bütünsel } \\
\text { bakış }\end{array}$ & 3 & $\begin{array}{l}\text { Eleştirel } \\
\text { sorgulama }\end{array}$ & 3 & & \\
\hline $\begin{array}{l}\text { İşbirlikli } \\
\text { ekip } \\
\text { çalışması }\end{array}$ & 5 & $\begin{array}{l}\text { Dinamik bir } \\
\text { zihin }\end{array}$ & 5 & Tasarım stili & 5 & & \\
\hline Toplam & 18 & Toplam & 17 & Toplam & 18 & Toplam & 6 \\
\hline
\end{tabular}

\section{Verilerin Analizi}

Verilerin toplanması işleminden sonra ölçeğin yapı geçerliği ve güvenirlik çalışmalarına geçilmiştir. Ölçeğin yapı geçerliği çalışması, açımlayıcı faktör analizi (AFA) yoluyla gerçekleşmiştir. Bu yapıyı doğrulamak içinse doğrulayici faktör analizi (DFA) uygulanmıştır.

Veri setinin faktör analizine uygun olup olmadığı belirlenirken dikkat edilmesi gereken en önemli noktalardan biri örneklem büyüklügüüür. Faktör analizi örneklem sayısına ilişkin faklı argümanlar bulunmaktadır. Argümanlarından biri her bir madde için beş katılımcı olması gerektiğidir (Child, 2006; Tabachnick ve Fidell, 2013). Bu kapsamda bu çalışmanın katılımcı sayısının (630) 59 maddelik taslak ölçek için yeterli olduğu söylenebilir. Veriler tesadüfi bir şekilde bölünerek analiz yapıldığından verilerin \%50'si (315) ile AFA, \%50'si (315) ile DFA analizi yapilmasi uygun (Hair, Black, Babin, Anderson ve Tatham, 2014) görülmüştür. Bir veri setinin faktör analizi için uygun olup olmadığını kontrol etmenin başka bir yolu da Kaiser-Mayer-Olkin (KMO) değerini incelemektir. Verilerin tutarlılığını tespit etmek için de Bartlett testi yapılmaktadır. Literatürde bir veri setinin faktör analizine uygun olabilmesi için KMO katsayısının 0.60 'tan büyük olması ve Bartlett'in küresellik testinin istatistiksel olarak anlamlı sonuç vermesi gerekmektedir (Büyüköztürk, 
2016; Pallant, 2016). Bu sebeple bu çalışmada AFA öncesi veri seti üzerinden KMO katsayısı hesaplanmış ve Bartlett testi yapılmıştır.

Faktörler arasında önemli bir korelasyon olduğundan faktörleri çıkarmak için temel bileşenler analizi (principal axis factoring) (Hair vd., 2014) tercih edilerek oblimin (delta $=0$ ) (direct oblimin) eğik döndürme kullanılmıştır. Eğik döndürme örtük değişkenlerin birbirleri ile ilişkili olduğu düşünülüyorsa tercih edilmektedir (Hair vd., 2014). Herhangi bir faktörde yer alan maddenin başka bir faktördeki yük değeri ile en az 0.10 fark olması tavsiye edilmektedir (Büyüköztürk, 2016; Kline, 2011). Bu nedenle bir maddenin birden fazla faktörün altında almış olduğu faktör yük değerleri arasında 0.10 düzeyinde bir farklılık oluşmaması sonucu madde çıkarılmasına karar verilmiştir. Ayrıca Tabachnick ve Fidell'e (2013) göre faktör yük değeri minimum 0.32 olması gerekmektedir. Faktör yük değeri 0.32' in altındaki maddeler de adım adım ölçekten çıkarılmıştır. Ölçeği oluşturan faktörler arasındaki ilişkiye de bakılmıştır. AFA ve korelasyon için IBM SPSS Statistics 25 kullanılmıştır. Model uyumunu değerlendirmek için maksimum olasılık tahmini analiziyle IBM SPSS Amos 19 programı ile doğrulayıcı faktör analizi yapılmıştır.

\section{Bulgular}

Bu bölümde TOD ölçeğinin geliştirilmesi sürecinde elde edilen yap1 geçerliliği ve güvenirlik bulgularına yer verilmiştir. Yapı geçerliğini test etmek amaciyla AFA, DFA, güvenirlik için Cronbach Alfa katsayısı ve faktörler arasi korelasyon değerleri bulguları açıklanmıştır.

\section{Açımlayıcı Faktör Analizi Bulguları}

Ölçeğin 59 maddesi temel bileşenler analizine alınmış ve eksen döndürmesi (direct oblimin) gerçekleştirilmiştir. AFA analizi ile KMO örneklem uygunluğu değeri kullanılarak örneklemin yeterliği ve Bartlett'in Küresellik Testi kullanılarak verilerin faktör analizine uygunluğu incelenmiş ve uygun bulunmuştur. Herhangi bir faktörde yer alan maddenin başka bir faktördeki yük değeri ile en az 0.10 fark olması tavsiye edildiğinden bir maddenin birden fazla faktörün altında almış olduğu faktör yük değerleri arasında 0.10 düzeyinde bir farklılık 
oluşmaması sonucu madde çıkarılmıştır. Faktör yük değeri 0.32 'in altındaki maddeler de adım adım ölçekten çıkarılmıştır. Bu verilerin incelenmesi sonucu 25 madde ile AFA sonuçları verilmiştir.

AFA analizinde KMO değeri 0.93 bulunmuş, Bartlett testi sonucunda ise istatistiksel olarak anlamlı farklılık $\left(x^{2}=3962.353, p=.000\right)$ olduğu görülerek veri seti faktör analizine uygun bulunmuştur. Açımlayıcı faktör analizi soncunda TODÖ 25 madde ile dört faktörlü yapıda oluşmuştur. AFA değerlendirilirken özdeğerlere ve yamaç birikinti grafiğine bakılmıştır. Özdeğer faktörlerce açılanan varyansı hesaplamada ve faktör sayısına karar vermede dikkate alınan bir katsayıdır (Büyüköztürk, 2016) ve bu değer 1 veya 1 'den büyük olması durumunda dikkate alınır. Temel bileşenler analizi 1'in üstünde özdeğere sahip olan dört tane bileşenin varlığını ortaya koymuştur (Tablo 4). Dört bileşenin yorumlanmasına yardımcı olmak için oblimin eğik döndürme gerçekleştirilmiştir.

\section{Tablo 4. Faktörlerin özdeğer dă̆ılımı}

\begin{tabular}{lllllll}
\hline & \multicolumn{2}{l}{ Başlangıç Özdeğerleri } & \multicolumn{3}{l}{ Açıllanan Varyans } \\
\cline { 2 - 7 } Faktör & Toplam & Varyans \% & Kümülatif $\%$ & Toplam & Varyans $\%$ & Kümülatif \% \\
\hline 1 & 9.92 & 39.68 & 39.68 & 9.44 & 37.75 & 37.75 \\
2 & 2.13 & 8.51 & 48.19 & 1.65 & 6.59 & 44.34 \\
3 & 1.25 & 4.99 & 53.18 & .78 & 3.11 & 47.45 \\
4 & 1.18 & 4.70 & 57.88 & .69 & 2.76 & 50.20 \\
\hline
\end{tabular}

İlk faktörün (ilişki) özdeğeri 9.92 ve toplam varyansın \%37.75'ini, ikinci faktörün (süreç) özdeğeri 2.13 ve toplam varyansın \%6.59'unu, üçüncü faktörün (etik) özdeğeri 1.25 ve toplam varyansın \%3.11'ini, dördüncü faktörün (birey) özdeğeri 1.18 ve toplam varyansın \%2.76'sini açıkladığ 1 tespit edilmiştir. Ölçeğin açıkladığı toplam varyans (\%50.20) ölçtüğü niteliği yeterince açıkladığını göstermektedir.

Ayrıca yamaç-birikinti grafiği ölçeğin faktör sayısına ilişkin kanıt sunmaktadır. Grafikte yüksek ivmeli, hızlı düşüşlerin yaşandığı noktalar faktör sayısını verir (Büyüköztürk, 2016; Child, 2006; Tabachnick ve Fidell, 2013). Faktör analizine ait yamaç birikinti grafiği incelendiğinde ölçeğin dört faktörlü olduğu görülmektedir (Şekil 1).

Hem özdeğer dağılımı hem yamaç birikinti grafiği ile TODÖ faktör yapısının dört boyutlu bir yapı ortaya koyduğu belirlenmiştir. Dördüncü 
faktörden sonra grafiğin genel gidişatının yatay seyrettiği ve yatay faktörlerin getirdikleri varyansların birbirine yakın olduğu görülmektedir.

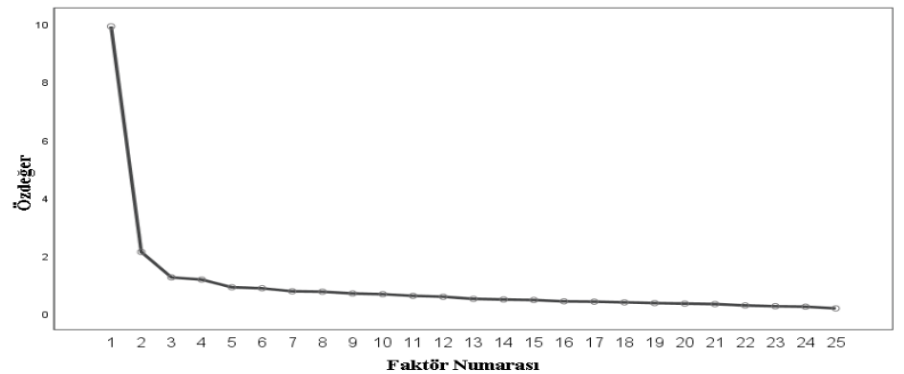

Şekil 1. TODÖ yamaç birikinti grafiği

$\mathrm{Bu}$ nedenle yatayda yer alan yapılar faktör olarak alınmaz. AFA sonucunda oluşan 25 madde ve faktör yük değerleri aşağıdaki tabloda verilmiştir.

Tablo 5. TODÖ madde faktör yükleri

\begin{tabular}{|c|c|c|c|c|}
\hline Maddeler & Madde İçeriği & $\begin{array}{l}\text { Faktörler } \\
\text { İlişki Süreç }\end{array}$ & Etik & Birey \\
\hline BireyMerkezli-5 & $\begin{array}{l}\text { Fikirleri/yöntemleri/araçları uygulamadan önce } \\
\text { insanlarla paylaşırım. }\end{array}$ & .851 & & \\
\hline BireyMerkezli-4 & İnsanları tasarım sürecine aktif olarak dâhil ederim. & .802 & & \\
\hline İsbirlikli-3 & $\begin{array}{l}\text { Süreç içerisinde aktif olarak başkalarıyla etkileşme } \\
\text { ihtiyacı duyarım. }\end{array}$ & .625 & & \\
\hline Yansitici-2 & $\begin{array}{l}\text { Tasarımın iyileştirilmesi için, insanlardan aldığım } \\
\text { dönütler üzerine düşünürüm. }\end{array}$ & .577 & & \\
\hline Yansitici-1 & $\begin{array}{l}\text { Tasarım sürecinde insanlar tarafından sunulan } \\
\text { fikirler üzerinde düşünürüm. }\end{array}$ & .542 & & \\
\hline İsbirlikli-1 & $\begin{array}{l}\text { En iyi tasarımları oluşturmak için insanlarla işbirliği } \\
\text { yaparım. }\end{array}$ & .537 & & \\
\hline Empati-4 & $\begin{array}{l}\text { Çözümü insanların bakış açısından görmeye } \\
\text { çalıştığımda kendimi iyi hissederim. }\end{array}$ & .530 & & \\
\hline Empati-1 & $\begin{array}{l}\text { Çözümü düşünürken kendimi, çözümden } \\
\text { etkileneceklerin yerine koyabilirim. }\end{array}$ & .492 & & \\
\hline BireyMerkezli-3 & İnsanların ihtiyaçlarını anlamak için zaman ayırırım. & .432 & & \\
\hline DinamikZihin-5 & $\begin{array}{l}\text { Çözüm tasarımında her zaman birden fazla yol } \\
\text { bulurum. }\end{array}$ & .763 & & \\
\hline ButunselBakis-3 & $\begin{array}{l}\text { Tasarımın insanlara ve çevreye etkilerini tahmin } \\
\text { ederim. }\end{array}$ & .702 & & \\
\hline YaraticiGuven-1 & Karmaşık problemlere yaratıcı çözümler üretirim. & .698 & & \\
\hline ButunselBakis-1 & Yaptıklarımı geniş bir bakış açısı ile düşünürüm. & .657 & & \\
\hline
\end{tabular}


DinamikZihin-2 Tasarım sürecinde zihnim, yeni fikirler üretmek ve bunları sınamak arasında gidip gelir.

DenemeYonelimi-3 Yeni teknolojik araçları uygulamak hoşuma gider.

Etik-2

Tasarımın yararının, oluşturabileceği muhtemel sorunlardan daha fazla olmasını önemserim.

Etik-4 Tasarımın etkisini, tasarımdan etkilenecek tüm taraflar açısından görmek gerektiğini düşünürüm.

Tasarım sürecinde mevcut tasarım fikirlerini dikkate almanın gereğine inanırım. düşünürüm.

Tabachnick ve Fidell'e (2013) göre faktör yük değeri minimum 0.32 olması gerekmektedir. Tüm maddelerin faktör yük değerinin 0.32 den büyük olduğu görülmektedir. Ölçekte yer alan 25 maddeye ilişkin faktör yük değerleri 0.85 - 0.38 arasında değişmektedir. Ayrıca görüldüğü üzere ölçeğin nihai formunda daha önce belirlenen özelliklerden en az biri ilgili boyutta yerini almıştır. Boyutların özellikleri Tablo 6 'da verilmiştir.

Tablo 6. TODÖ boyutları özellikleri

\begin{tabular}{ll}
\hline Boyut & Özellikler \\
\hline İlişki & $\begin{array}{l}\text { Bu boyut, öğretmenin süreçteki ilişkilerini temsil etmektedir. Bunlar birey merkezli, empatik, } \\
\text { yansıtıcı, işbirlikli ekip çalışması maddelerine karşılık gelmektedir. }\end{array}$ \\
\hline Süreç & $\begin{array}{l}\text { Bu boyut, öğretmenin süreç ile ilgili yaklaşımını temsil etmektedir. Bunlar deneme yönelimi/risk } \\
\text { almaya açıklık, yaratıcı güven, bütünsel bakış, dinamik bir zihin maddelerine karşlık gelmektedir. }\end{array}$ \\
\hline Etik & Bu boyut, bireylerin ilişki ve süreçlerinde etik değerlerine karşılık gelen maddeleri içermektedir. \\
\hline Birey & $\begin{array}{l}\text { Bu boyut, öğretmenin kişiliğini yansıtan özellikleri temsil etmektedir. Bunlar yenilikçi/belirsizlikte } \\
\text { rahat, iyimserlik, eleştirel sorgulama, tasarım stili maddelerine karşıllk gelmektedir. }\end{array}$ \\
\hline
\end{tabular}

Birinci faktör TOD sürecinin temelini oluşturan ilişki söylemlerini ifade eden boyut olup 9 maddeden, ikinci boyutu süreç olup 6 maddeden, süreç tabanında ilişki odağında tasarımın üçüncü boyutu etik olup 4 
maddeden ve son olarak da bireyin kişisel özelliklerini ifade eden dördüncü boyut 6 maddeden oluşmaktadır.

\section{Doğrulayıcı Faktör Analizi Bulguları}

AFA sonucu ile TODÖ 4 faktörlü bir yapıda oluşmuştur. Belirlenen faktör yapısının elde edilen verilere ne kadar uygun olduğunu test etmek için maksimum olasılık tahmini analiziyle DFA yapılmıştır. DFA'nın değerlendirilmesinde diyagram, uyum iyiliği ve düzeltme önerileri dikkate alınmıştır. Uyum iyiliğini yakalamak için hata terimlerinin kovaryansları eşleştirilmesi yapılabilmektedir. Hata kovaryanslarına ilişkin düzeltmeler iki değişkenden birisinin gereksiz olduğu veya katılımclar tarafından aynı şekilde anlaşıldığı anlamına gelmektedir. Dolayısıyla program aracılığıyla bu iki değişken arasındaki hata terimlerinin kovaryanslarını eşleştirmesi gerekir.

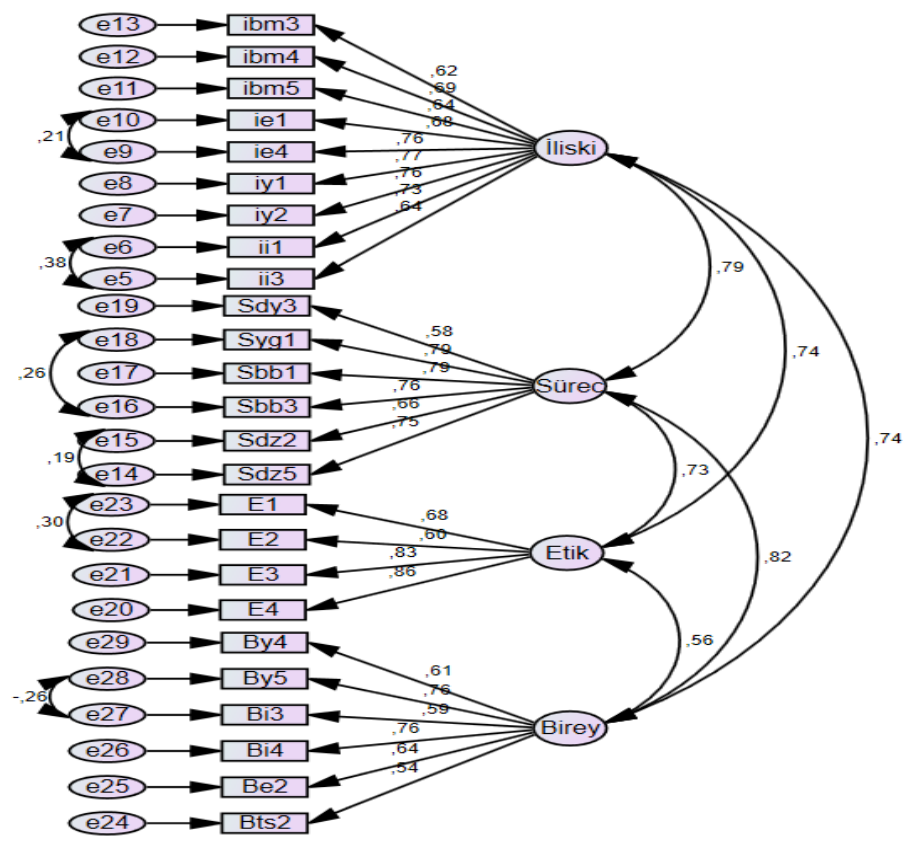

$\mathrm{CMIN}=430,598 ; \mathrm{DF}=263 ; \mathrm{CMIN} / \mathrm{DF}=1,637 ; \mathrm{p}=, 000 ; \mathrm{RMSEA}=, 045 ; \mathrm{CFI}=, 959 ; \mathrm{GFI}=, 900$ Şekil 2. TODÖ alt boyutlarının birbiriyle ilişkisini gösteren dört faktörlü model 
Alanyazına göre 5 ve daha az maddeden oluşan faktörlerde en fazla 1, 6 ve 11 maddeden oluşan faktörlerde en fazla 2 ve 12 'den fazla maddelerden oluşan faktörlerde ise en fazla 3 düzeltme önerilmektedir (Gürbüz, 2019). Çalışma kapsamında bu dağılıma dikkat edilerek birinci faktörde iki, ikinci faktörde iki, üçüncü faktörde bir ve dördüncü faktörde bir hata terimi kovaryansları eşleştirilmesi yapılmıştır. Eşleştirmelerin ardından analiz tekrarlanmıştır. Diyagramda hata terimlerinin kovaryansları eşleştirmeleri ve her bir maddenin kendi örtük değişkenini ne kadar iyi temsil ettiğine dair bilgi veren standartlaştırılmış değerler gösterilmiştir. DFA'ya ilişkin diyagram Şekil 2'de verilmiştir.

Ölçeğin belirlenen faktör yapısının geçerliliği DFA ile test edilmiştir. Literatürde yer alan DFA uyum iyiliği aralıkları (Gürbüz, 2019) ve DFA sonucu elde edilen değerler Tablo 7 ' de verilmiştir.

Tablo 7. TODÖ DFA uyum iyiliği indeksleri, elde edilen uyum iyiliği indeksleri ve karar

\begin{tabular}{lllll}
\hline İndeks & İyi uyum & Kabul edilebilir & $\begin{array}{l}\text { Elde Edilen } \\
\text { Değerler }\end{array}$ & Karar \\
\hline $\begin{array}{l}\mathrm{CMIN}\left(\mathrm{X}^{2}\right) / \mathrm{df} \\
(\text { Chi-Square/df })\end{array}$ & $.00 \leq\left(x^{2} / \mathrm{df}\right)<2.00$ & $2.00 \leq\left(x^{2} / d f\right) \leq 5.00$ & 1.64 & İyi uyum \\
\hline RMSEA & $.00 \leq \mathrm{RMSEA}<.05$ & $.05 \leq \mathrm{SRMR} \leq .10$ & .045 & İyi uyum \\
\hline SRMR & $.00 \leq \mathrm{SRMR}<.05$ & $.05 \leq \mathrm{SRMR} \leq .10$ & .043 & İyi uyum \\
\hline IFI & $.95 \leq \mathrm{NFI} \leq 1.00$ & $.90 \leq \mathrm{NFI} \leq .95$ & .96 & İyi uyum \\
\hline CFI & $.97 \leq \mathrm{CFI} \leq 1.00$ & $.95 \leq \mathrm{CFI} \leq .97$ & .96 & $\begin{array}{l}\text { Kabul } \\
\text { edilebilir }\end{array}$ \\
\hline NNFI & $.95 \leq \mathrm{NFI} \leq 1.00$ & $.90 \leq \mathrm{NFI} \leq .95$ & .95 & $\begin{array}{l}\text { Kabul } \\
\text { edilebilir }\end{array}$ \\
\hline GFI & $.95 \leq \mathrm{NFI} \leq 1.00$ & $.85 \leq \mathrm{GFI} \leq .95$ & .90 & $\begin{array}{l}\text { Kabul } \\
\text { edilebilir }\end{array}$ \\
\hline NFI & $.95 \leq \mathrm{NFI} \leq 1.00$ & $.90 \leq \mathrm{NFI} \leq .95$ & .90 & $\begin{array}{l}\text { Kabul } \\
\text { edilebilir }\end{array}$ \\
\hline
\end{tabular}

Doğrulayıcı faktör analiz sonucunda elde edilen uyum iyiliği değerleri $\left(x^{2}[d f=263, N=315]=430.598 ; p<.001, x^{2} / d f=1.637 ; \mathrm{CFI}=.96 ;\right.$ RMSEA = $.045 ; \mathrm{SRMR}=.043 ; \mathrm{NNFI}=.95 ; \mathrm{GFI}=.90 ; \mathrm{NFI}=.90 ; \mathrm{IFI}=.96)$ önerilen dört faktörlü modelin veri ile uyumlu ve kabul edilebilir olduğunu göstermektedir. Bu sonuçlar TOD ölçeğinin öngörülen kuramsal yapısının doğrulandığı söylemektedir. 


\section{Güvenirlik Katsayıları}

AFA ve DFA sonucu elde edilen ölçütlere göre, tasarım odaklı düşünme ölçeğinde yer alan maddelerin elde edilen dört alt boyuttaki yapılarla ilgili modellerinin uygun olduğu kararına varılmıştır. Ölçeğin güvenirliğinin belirlenmesi amacıyla AFA verileri üzerinde güvenirlik katsayısı (Cronbach Alfa) hesaplaması yapılmıştır. Her bir faktöre ve toplama ait iç tutarlılık katsayıları hesaplanmış ve yüksek bulunmuştur. Nunnally'e (1978) göre kabul edilebilir en az güvenirlik katsayısı 0.70'dir. TOD ölçeği için toplam iç tutarlılık güvenirliği Cronbach Alfa katsayısı değeri .93 olarak bulunmuştur. Alt boyutların madde sayıları ve Cronbach Alfa katsayıları da Tablo 8'de görülmektedir.

Tablo 8. TODÖ boyut madde sayıları ve güvenirliği

\begin{tabular}{llcc}
\hline \multicolumn{2}{l}{ Faktör } & Madde sayısı & Cronbach Alfa Katsayısı \\
\hline 1. & İlişki & 9 & .90 \\
2. & Süreç & 6 & .86 \\
3. & Etik & 4 & .81 \\
$4 . \quad$ Birey & 6 & .81 \\
\multicolumn{2}{l}{ Toplam } & 25 & .93 \\
\hline
\end{tabular}

Alt boyutlara ilişkin güvenirlik katsayıları tavsiye edilen 0.70 (Nunnally, 1978) değerini aşarak yeterli iç tutarlılığı göstermiştir. Cronbach Alfa Katsayısı ölçeğin yüksek derecede güvenilir olduğunu göstermektedir. Bu durumda TOD ölçeğinin oldukça yüksek güvenirliğe sahip olduğu söylenebilir.

\section{Faktörler Arası Korelasyon Değerleri}

Faktörlerin korelasyon matrisi incelendiğinde ise faktörlerin birbiriyle ilişkisinin pozitif ve oldukça yüksek değerlere sahip olduğu görülmektedir (Tablo 9).

Tablo 9. TODÖ faktörler arası korelasyon değerleri

\begin{tabular}{lllll}
\hline Faktör & 1 (İlişki) & 2 (Süreç) & 3 (Etik) & 4 (Birey) \\
\hline 1 (İlişki) & 1.00 & & & \\
2 (Süreç) & .58 & 1.00 & & \\
3 (Etik) & .61 & .43 & 1.00 & \\
4 (Birey) & .49 & .63 & .31 & 1.00 \\
\hline
\end{tabular}


$\mathrm{Bu}$ durumda TOD ölçeğiyle ilgili korelasyon katsayısı faktörler arasında anlamlı ve yüksek düzeyde ilişkinin olduğunu söylenebilir. Bu sonuç, bir faktöre ilişkin oluşacak değer değişimi, artış veya azalış, paralel olarak diğer faktörlerin de değişmesine sebep olacağını göstermektedir.

Sonuç olarak dört faktörden oluşan TODÖ, bütün branş ve kademeden öğretim tasarımı yapan her öğretmenin tasarımlarına yönelik TOD yapılarını ölçmek amacıyla Türkiye'de geliştirilen ilk ölçektir.

\section{Tartışma ve Sonuç}

$\mathrm{Bu}$ araştırmada, öğretmenlerin öğretim süreçleri tasarımında, TOD özyeterliklerini ölçmeye yönelik geçerli ve güvenilir bir ölçek geliştirilmiştir. Öz raporlamaya dayalı ölçeğin geliştirilme süreci, alanyazın taraması ile başlamış ve ölçek geliştirme adımları izlenerek gerçekleştirilmiştir. Görünüş ve kapsam açısından uzman görüşü alınmış, yapı geçerliği için AFA, DFA ve iç tutarlık ölçümleri yapılmıştır.

Geliştirilen ölçek 6'lı likert türü cevap formatına dayalı 25 madde içermekte ve dört faktörden (ilişki, süreç, etik ve birey) oluşmaktadır. Ölçekte yer alan 25 maddenin 9'u ilişki, 6'sı süreç, 4'ü etik ve 6'sı birey faktörlerinde yer almaktadır. Ayrıca ölçekte yer alan faktörler toplam varyansın \%50.20'sini açıklamaktadır. İç tutarlık ölçümleri hem toplamda hem de alt faktörlerde yüksek bulunmuştur ve DFA yapılarak uyum iyiliği değerleri kabul edilebilir aralıkta sonuçlanmıştır. Ölçekte, ilişki, süreç, etik ve birey faktörleri ile ilgili olarak öğretmenlerin öğretim tasarımındaki TOD öz yeterlilikleri belirlenmektedir. TOD ölçeğine ilişkin yapılan geçerlik ve güvenirlik analizleri sonucunda, geçerli ve güvenilir bir ölçme aracı olduğu kabul edilebilir.

Alanyazın taraması ile tasarım odaklı düşünür için belirlenen 13 özelliğin her birini temsil edecek en az bir madde ölçekte yer alarak dört faktör altında toplanmıştır. Ölçeğin ilişki boyutunda öğretmenin süreçteki ilişkilerini yansıtan insan merkezli, empatik, yansıtıcı, işbirlikli ekip çalışması özellikleri yer almıştır. Ölçeğin süreç boyutunda öğretmenin öğretim tasarımı süreci ile ilgili yaklaşımını yansıtan deneme yönelimi/risk almaya açıklık, yaratıcı güven, bütünsel bakış, dinamik bir zihin özellikleri öne çıkmıştır. Ölçeğin etik boyutunda öğretmenin 
bireysel ve ilişkisel süreçlerindeki etik değerlere karşılık gelen özellikleri yer almıştır. Ölçeğin birey boyutunda öğretim tasarımlarında öğretmenin kendine dair farkındalığını yansıtan yenilikçi/belirsizlikte rahat, iyimserlik, eleştirel sorgulama, tasarım stili özelliklerine karşılık gelmiştir.

Mevcut alanyazın incelendiğinde öğretim tasarımı ve teknolojisi alanında öğretmenlerin TOD yapılarını ölçmeye yönelik bir araca rastlanılmamıştır. Dosi vd. (2018) bütün tasarımcılar için 71 maddeli 22 faktörlü TOD anketi geliştirmiştir. Chesson (2017) bireylerde TOD yeteneklerini değerlendirmek için bir ölçek geliştirmiştir ve bu ölçek 27 maddeli 6 faktörden oluşmaktadır. Chesson (2017) geliştirdiği ölçeğin kuruluşlarda çalışan, yönetici, uygulayıcı, eğitimci, liderler için yararlı olacağını savunmaktadır. Diğer TOD veri toplama araçları incelendiğinde öğretim tasarımı ve teknolojisi alanında kullanılması olanaklı görülmemiştir. Rastlanan araştırmalar incelendiğinde geliştirilen veri toplama araçları oldukça genel katılımcıları ya da oldukça özel alan tasarımcılarını hedeflemektedir ve etik boyutu göz ardı edilmiştir. Bu çalışma kapsamında geliştirilen ölçek, teknoloji tabanlı öğretim tasarımı sürecinde öğretmenlere yönelik ilişkileri, süreci, bireysel özellikleri ve etik ilkeleri temsil etmektedir.

Araştırma, alanyazın kapsamında yararlanılan kaynaklarla ve ayn zamanda 2019-2020 öğretim yılı yaz döneminde Türkiye'nin çeşitli yerlerinde görev yapan 630 öğretmenden elde edilen veriler ile sınırlanmaktadır. Her ölçek, maddelerinin ölçebildiği kadarı ile sınırlıdır bu nedenle TOD, ancak bu ölçek maddelerinin yapabileceği ölçüm çerçevesinde yorumlanabilir.

Ölçeğin kullanım alanları, TOD atölyeleri veya projelerinde öğretmenlerin tutumlarının değişip değişmediğini test etmek için süreç öncesi ve sonrasında ölçek kullanılabilir. Atölye veya proje başlangıçlarında takım üyelerinin tutumlarını önceden bilerek tasarım ekiplerini oluşturmak için bir araç olarak da kullanılabilir. Araştırmacılar tasarım eğitimi pedagojik müdahalesinde, araştırma projelerinde, TOD yapısına göre takımlar oluşturup gelişimi değerlendirilebilir veya TOD konusunda deneyim sahibi olan öğretmenlerle çalışılıp son durumda TOD durumu incelenebilir. 
EXTENDED ABSTRACT

\section{Development of Design Thinking Scale in Teaching}

*

\author{
Yeşim Sürmelioğlu - Mukaddes Erdem \\ Hacettepe University- Hacettepe University
}

An inventory development study is needed in instructional design field to measure the design thinking of teachers. For this reason, it was decided to develop a Design Thinking Scale for teachers in the technology-based instructional design process.

This research is conducted to develop a valid and reliable scale. A measurement tool that determines the design thinking structures of teachers based on the results of exploratory and confirmatory factor analysis was developed within the scope of the research.

The study consisted of 630 teachers working in different branches and at different levels, in various regions of Turkey. First, based on the studies in the literature, we created a four-dimensional item pool which consists of 62 items representing the characteristics of design thinker. We took the preliminary opinions of 5 teachers from different branches about the first draft items, and reduced the number of items to 59 by evaluating their opinions. Then, we consulted 8 expert opinions in terms of the scope and appearance of the inventory. We rearranged the items according to the suggestions, and prepared a draft form with 59 items and made ready for implementation. It is a 6-point Likert scale ( 0 for irrelevant, 5 for exactly relevant). The scale was delivered to teachers via digital form.

It is recommended to have 5 participants for each item in factor analysis, so we accepted it as sufficient to provide validity and reliability in this study (Tabachnick \& Fidell, 2013; Child, 2006). Since the data is divided to analyze, it is deemed appropriate to perform an exploratory factor analysis with $50 \%$ (315) of the data, and confirmatory factor analysis with 50\% (315) (Hair et al., 2014). In order for a data set to be suitable for factor analysis according to the literature, the KMO coefficient should be greater than 0.60 and Bartlett's test of sphericity should give statistically significant results (Büyüköztürk, 2016; Pallant, 2016). So, we examined these values. 
Principal axis factoring analysis is preferred to extract factors, as there is an important correlation between factors, and direct oblimin (delta $=0$ ) oblique rotation is preferred if implicit variables are thought to be related to each other (Hair et al., 2014). It is recommended that the item in any factor should have at least 0.10 difference with the load value of another factor (Büyüköztürk, 2016; Kline, 2011) and the factor load value should be minimum 0.32 (Tabachnick \& Fidell, 2007). We took these suggestions into consideration in the study. We performed confirmatory factor analysis with maximum probability estimation analysis to evaluate model-data fit.

\section{Findings}

The KMO value was found to be 0.93 . The data set was found suitable for the factor analysis since the Bartlett test found a statistically significant difference $\left(x^{2}=3962.353, p=.000\right)$. Principal axis factoring analysis revealed the existence of four components with eigenvalues above 1 . A four-factor structure with 25 items was obtained as a result of the exploratory factor analysis. Factor load values vary between 0.85 and 0.38 for the 25 items in the scale.

The relationship dimension of the scale consists of 9 items and the features of individual-centered, empathic, reflective, collaborative teamwork reflecting the teacher's relations in the process. The process dimension of the scale consists of 6 items and the features of experimentality/openness to take risk, creative trust, holistic view, and a dynamic mind reflecting the teacher's approach to the instructional design process. The ethical dimension of the scale consists of 4 items, and the teacher's characteristics corresponding to ethical values in individual and relational processes. The individual dimension of the scale consisted of 6 items corresponded to the innovative/comfortable in ambiguity, optimism, critical questioning, and design style characteristics reflecting the individual qualities of the teacher.

The internal consistency coefficients for each factor and total were calculated and found to be high. The total Cronbach's Alpha reliability value was found to be .93 for the Design Thinking Inventory, .90 for the relationship dimension, .86 for the process dimension, .81 for the ethics 
dimension, and .81 for the individual dimension. The correlation matrix of the factors showed that the relation of the factors with each other was positive and had very high values.

The diagram, goodness of fit, and improvement suggestions were taken into account in the evaluation of the confirmatory factor analysis. Goodness of fit values obtained as a result of confirmatory factor analysis $\left(X^{2}[\mathrm{df}=263, \mathrm{~N}=315]=430.598 ; p<.001, \mathrm{X}^{2} / \mathrm{Sd}=1.637 ; \mathrm{CFI}=.96\right.$; RMSEA $=.045 ; \mathrm{SRMR}=.043 ; \mathrm{NNFI}=.95 ; \mathrm{GFI}=.90 ; \mathrm{NFI}=.90 ; \mathrm{IFI}=.96)$ show that the proposed four-factor model is compatible with the data and acceptable. These results show that the predicted theoretical structure of the Design Thinking Scale is confirmed.

\section{Discussion and Conclusion}

This research has been carried out to develop a valid and reliable scale, which is planned to be used to measure the design thinking structures of teachers in the technology-based instructional design process. We developed a six-point Likert type scale containing 25 items and four dimensions. In addition, factors in the scale explain $50.20 \%$ of the total variance. Internal consistency measurements were found to be high in both total and sub-factors. The goodness of fit values was found to be within an acceptable range after performing a confirmatory factor analysis. The result of the validity and reliability analysis of the Design Thinking Scale showed that it can be accepted as a valid and reliable measurement tool. One of the original values of the developed scale is that teachers should question the ethical dimension in individual level or in relationships at any stage of the instructional design process.

The scale can be used before and after a design thinking project to test whether teachers' attitudes have changed. It can also be used as a tool to build design teams by knowing the team members' attitudes in advance at project start-ups. Researchers can form teams in design education pedagogical intervention, research projects according to the design thinking structure and evaluate their development with the help of this scale. 


\section{Kaynakça / References}

Akdemir, N. (2017). Tasarım kavramının geniş çerçevesi: Tasarım odaklı yaklaşımlar üzerine bir inceleme. ODÜ Sosyal Bilimler Araştırmaları Dergisi, 7(1), 85-94.

Association for Educational Communications and Technology [AECT]. (2018). Instructional design definition. Retrieved from https://www.aect.org/.

Blizzard, J., Klotz, L., Potvin, G., Hazari, Z., Cribbs, J., and Godwin, A. (2015). Using survey questions to identify and learn more about those who exhibit design thinking traits. Design Studies, 38, 92-110. http://dx.doi.org/10.1016/j.destud.2015.02.002

Boni, A. A., Weingart, L. R., and Evenson, S. (2009). Innovation in an academic setting: Designing and leading a business through market-focused, interdisciplinary teams. Academy of Management Learning \& Education, 8(3), 407-417. https://doi.org/10.5465/amle.8.3.zqr407

Bozkurt, A. (2020). Koronavirüs (Covid-19) pandemi süreci ve pandemi sonrası dünyada eğitime yönelik değerlendirmeler: Yeni normal ve yeni eğitim paradigması. Açı̈öğretim Uygulamaları ve Araştırmaları Dergisi, 6(3), 112-142.

Bozkurt, A., and Sharma, R. C. (2020). Emergency remote teaching in a time of global crisis due to CoronaVirus pandemic. Asian Journal of Distance Education, 15(1), i-vi. https://doi.org/10.5281/zenodo.3778083

Brenner, W., Uebernickel, F., and Abrell, T. (2016). Design thinking as mindset, process, and toolbox. In Design thinking for innovation (pp. 321). Springer, Cham. doi: 10.1007/978-3-319-26100-3_1

Brown, T. (2008). Design thinking. Harvard business review, 86(6), 84-92.

Buchanan, R. (1992). Wicked problems in design thinking. Design issues, 8(2), $5-21$.

Büyüköztürk, Ş. (2002). Factor analysis: Basic concepts and using to development scale. Educational Administration in Theory and Practice, 32(32), 470-483.

Büyüköztürk, Ş. (2016). Sosyal bilimler için veri analizi el kitabı istatistik, araştırma deseni SPSS uygulamalar ve yorum, Ankara: Pegem Akademi.

Chesson, D. (2017). Design thinker profile: creating and validating a scale for measuring design thinking capabilities. (Doctoral dissertation). Antioch University. 
Child, D. (2006). The essentials of factor analysis. London: Continuum International Publishing Group.

Cross, N. (1982). Designerly ways of knowing. Design studies, 3(4), 221-227. https://doi.org/10.1016/0142-694X(82)90040-0

Design Council, (2019). What is the framework for innovation? Retrieved from https://www.designcouncil.org.uk/news-opinion/what-frameworkinnovation-design-councils-evolved-double-diamond.

DeVellis, R. F. (2016). Scale development: Theory and applications (Vol. 26). Sage publications.

Doppelt, Y. (2009). Assessing creative thinking in design-based learning. International Journal of Technology and Design Education, 19(1), 55-65. doi: 10.1007/s10798-006-9008-y

Dorst, K. (2010). The nature of design thinking. In Design thinking research symposium. DAB Documents.

Dosi, C., Rosati, F., and Vignoli, M. (2018). Measuring design thinking mindset. In DS 92: Proceedings of the DESIGN 2018 15th International Design Conference (pp.1991-2002). https://doi.org/10.21278/idc.2018.0493

Erdem, M. (2020). Yeniden öğretmeyi öğrenmek: Organizmadan bireye öğretim süreçleri tasarımı. Ankara: Pegem Akademi.

Friedman, K. (2003). Theory construction in design research: criteria: approaches, and methods. Design studies, 24(6), 507-522. https://doi.org/10.1016/S0142-694X(03)00039-5

Greene, M. T., Gonzalez, R., and Papalambros, P. Y. (2019, July). Measuring systems engineering and design thinking attitudes. In Proceedings of the Design Society: International Conference on Engineering Design (Vol. 1, No. 1, pp. 3939-3948). Cambridge University Press. https://doi.org/10.1017/dsi.2019.401

Gürbüz, S. (2019). AMOS ile yapısal eşitlik modellemesi. Ankara: Seçkin Yayıncilik.

Hair, J. F., Black, W. C., Babin, B. J., Anderson, R. E., and Tatham, R. L. (2014). Multivariate data analysis, 5(3), 207-219. Upper Saddle River, NJ: Prentice hall.

Howard, Z., and Davis, K. (2011). From solving puzzles to designing solutions: Integrating design thinking into evidence based practice. Evidence Based Library and Information Practice, 6(4), 15-21. 
Johansson-Sköldberg, U., Woodilla, J., and Çetinkaya, M. (2013). Design thinking: past, present and possible futures. Creativity and innovation management, 22(2), 121-146. https://doi.org/10.1111/caim.12023

Junginger, S. (2007). Learning to design: giving purpose to heart, hand and mind. Journal of Business Strategy, 28(4), 59-65. https://doi.org/10.1108/02756660710760953

Kimbell, L. (2011). Rethinking design thinking: Part I. Design and Culture, 3(3), 285-306. https://doi.org/10.2752/175470811X13071166525216

Kline, R. B. (2011). Convergence of structural equation modeling and multilevel modeling (pp. 562-589). https://dx.doi.org/10.4135/9781446268261.n31

Kröper, M., Fay, D., Lindberg, T., and Meinel, C. (2010). Interrelations between motivation, creativity and emotions in design thinking processes - An empirical study based on regulatory focus theory. In Proceedings of the 1st International Conference on Design Creativity ICDC 2010 (pp. 97104), Kobe, Japan, November 2010.

Liedtka, J. (2015). Perspective: Linking design thinking with innovation outcomes through cognitive bias reduction. Journal of product innovation management, 32(6), 925-938. https://doi.org/10.1111/jpim.12163

Liedtka, J. (2018). Exploring the impact of design thinking in action. Darden Working Paper Series.

Martin, R., and Martin, R. L. (2009). The design of business: Why design thinking is the next competitive advantage. Harvard Business Press.

Nunnally, J. C. (1978). Psychometric Theory: $2 d$ Ed. McGraw-Hill.

Owen, C. (2007). Design thinking: Notes on its nature and use. Design Research Quarterly, 2(1), 16-27.

Pallant, J. (2016). SPSS survival manual: A step by step guide to data analysis using IBM SPSS (6th ed.). London: McGraw-Hill Education.

Rauth, I., Köppen, E., Jobst, B., and Meinel, C. (2010). Design thinking: an educational model towards creative confidence. In DS 66-2: Proceedings of the 1st international conference on design creativity (ICDC 2010).

Razzouk, R., and Shute, V. (2012). What is design thinking and why is it important? Review of educational research, 82(3), 330-348. https://doi.org/10.3102/0034654312457429 
Reigeluth, C. M. (1999). What is instructional-design theory and how is it changing. Instructional-design theories and models: A new paradigm of instructional theory, 2, 5-29.

Rittel, H. W., and Webber, M. M. (1973). Dilemmas in a general theory of planning. Policy sciences, 4(2), 155-175.

Rusmann, A., and Bundsgaard, J. (2019, October). Developing a Test to Measure Design Thinking. In European Conference on Games Based Learning (pp. 587-XXII). Academic Conferences International Limited. doi: 10.34190/GBL.19.071

Scheer, A., Noweski, C., and Meinel, C. (2012). Transforming constructivist learning into action: Design thinking in education. Design and Technology Education: An International Journal, 17(3), 8-19.

Şeker, H., and Gençdoğan, B. (2014). Psikolojide ve eğitimde ölçme aracı geliştirme. Ankara: Nobel.

Tabachnick, B. G., and Fidell, L. S. (2013). Using multivariate statistics: International edition. Pearson 2012.

Tezbaşaran, A. (1997). Likert tipi ölçek geliştirme kılavuzu. Ankara: Türk Psikologlar Derneği.

The Interaction Design Foundation [IDF] (2020). 5 Stages in the Design Thinking Process. Retrieved from https://www.interactiondesign.org/literature/article/5-stages-in-the-design-thinking-process.

Tsai, C. C., and Chai, C. S. (2012). The" third"-order barrier for technologyintegration instruction: Implications for teacher education. Australasian Journal of Educational Technology, 28(6). https://doi.org/10.14742/ajet.810

Türk Dil Kurumu [TDK]. (2020). Güncel Türkçe Sözlük. 27 Kasım 2020 tarihinde https://sozluk.gov.tr/ adresinden erişildi.

\section{Kaynakça Bilgisi / Citation Information}

Sürmelioğlu, Y. ve Erdem, M. (2021). Öğretimde tasarım odaklı düşünme ölçeğinin geliştirilmesi. OPUS-Uluslararası Toplum Araştırmaları Dergisi, 18(39), 223-254. DOI: 10.26466/opus.833362. 